\title{
Sustainable Management Modeling of Mangrove Ecosystem to Support the Local Economy in Small Islands, South Sulawesi Indonesia
}

\author{
Amal ARFAN ${ }^{1 *}$, Wahidah SANUSI1 ${ }^{1}$, Muhammad RAKIB ${ }^{2}$, Nur Anny Suryaningsih \\ TUUFIEQ $^{3}$, Nur Fatimah BASRAM ${ }^{1}$ \\ ${ }^{1}$ Faculty of Mathematics and Natural Sciences, Universitas Negeri Makassar, Indonesia \\ ${ }^{2}$ Faculty of Economic, Universitas Negeri Makassar, Indonesia \\ ${ }^{3}$ Faculty of Engineering, Universitas Negeri Makassar, Indonesia
}

Received: 19/09/2020

Accepted: 22/11/2020

Published: 20/03/2021

\begin{abstract}
The model starts with the formation of groups of fishermen/farmers /mangroves/women. The group produces something from mangrove forest that comes from creativity and ability to create something new as well as utilizing their members based on their abilities. After the formation of productive, creative and innovative groups of fishermen/ farmers / mangroves, the values are assessed and provided some benefits. Before going to the next stage, reflection on the groups formed is under the goals and objectives of the group formation. After reflection, it conducts a study of the suitability of the business sector that is carried out in the mangrove forest area. The suitability of the business sector must be based on environmentally friendly systems and mangrove conservation. It is called cultivation with the silvofishery system (integrating shrimp/fish cultivation with mangroves) and the use of environmentally friendly fishing tools. The next step is to formulate academic methods, then lay down the urgency and management paradigm of putting something important and the main patterns and models in the management of mangrove forests. After that phase, fixing management problems of mangrove forest. Mangrove forest management involves local communities and other stakeholders meanwhile the government, in this case, acting as a motivator and facilitator because of its understanding of the A. formosa growth and dynamics in the tropical coral reef ecosystems.
\end{abstract}

Keywords: Community; Mangrove ecosystem; Modelling; Small islands; Sustainable management

\section{Introduction}

Mangrove is one of the marine ecosystems which has the most productive ecological function of the earth because it provides a unique habitat for a variety of species [1]. Mangrove forest provides essential services throughout the world including goods and services which are important for humans worth US \$194,000 ha year-1 [2, 3]. Mangrove forest ha many functions and benefits which plays an important role in the occupant's life for biological, ecological, physical and socioeconomic [4-8]. Mangrove area as a protected area used to be a source of raw materials for the daily life of local people that can serve as a tourism facility, a cultural and spiritual identity, and provide ecological services to the surrounding environment [9-14]. Generally grow in wet soil, saltwater and periodically submerged by tidal currents along the coast are protected, estuaries and river areas in tropical

*Corresponding author: Amal ARFAN, Faculty of Mathematics and Natural Sciences, Universitas Negeri Makassar, Indonesia. E-mail: amalarfan@unm.ac.id and subtropical latitudes [15]. Mangrove forest has high adaptability, to survive extreme tidal conditions [16], high temperature [17], high salinity [18] and tropical storms [19]. As a result, mangrove forest forms productive ecosystems $[20,21]$. As one of the biggest archipelago countries, Indonesia has massive potential in marine resources. This biggest asset can be applied to enhance the Indonesian's life quality. One of the marine sources that have massive potential is the mangrove ecosystem. It estimated that mangrove has value around \$200.000 - \$900.000 per hectare and uses it as a prime livelihood [22]. Furthermore, many people rely on their life on mangrove ecosystem especially in tropical areas [23]. In addition, mangrove can create a habitat in which various species either flora or fauna may live there and apply it as shelter and nesting [24-26].

Mangroves are also important for people, for various purposes, including fisheries, agriculture, forestry, material sourcing, protection against marine erosion, and typhoons, absorption of pollution, as well as to support the fishing industry, coastal, nursery habitat, spawning and breeding for birds, mammals, fish, crustaceans, shellfish and reptile [27- 
32]. Proper management and utilization of the mangrove ecosystem will have a direct impact on the communities around the mangrove area. [33] revealed that there are four types of suitable management in mangrove forest areas that can be directly be benefited concerning the communities such as the utilization of mullet fishing, the utilization of aquaculture/milkfish ponds and tiger shrimp, the utilization of mangrove seeds, and the utilization of mangrove fruit. Furthermore, [34] stated that sustainable mangrove forest management is the best activity in order to be applied in land use and forest products in coastal areas. Good management of mangrove forests by prioritizing fast action consisted of utilizing opportunities and maintaining strength (growthoriented strategy). In addition, [35] revealed that the sustainability status of mangrove ecosystem management is largely determined by the quality of the environment. Poor environmental quality led by anthropogenic activities will affect the entire mangrove ecosystem. Another benefit that can also be obtained from the mangrove ecosystem is implementing ecotourism. [36] stated that the development of mangrove ecotourism from the social aspect can provide convenience activities and improving environmental conditions as well as welfare while in economic aspects, it can create job opportunities and in agribusiness aspect, it can support communities to make syrup and chips from mangrove fruits. Most people, in order to fulfill their life necessity and several other factors, culled the mangrove forests.

The Mangrove forest is also threatened as a result of industry and agriculture aquaculture [37], extraction of salt [38], heavy metal contamination [39], oil pollution [40, 41]. Meanwhile, the mangrove forest is contributing to the economy that can improve the welfare of the community independently and sustainably. Economic assessment of the mangrove ecosystems has been carried out in several mangrove forests. At the Gulf of Thailand, services are provided in the form of fisheries worth US\$ 33-110 ha-1 year1 [42], Ras Mohammad National Park, Egypt services provided in the form of socio-economic services (income, employment, etc. worth US\$ 91,000ha-1 year $^{-1}$ [43], in Miani Hor Pakistan the services provided were in the form of fisheries worth US\$ 1,287 $\mathrm{ha}^{-1}$ year-1 [44], Southeast Asia services provided were Fisheries, firewood, coastal protection worth US\$ 239- 4,185 ha year $^{-1}$ [45], Can Gio, Vietnam services provided are Fisheries, forest products, aesthetics and recreation and climate change mitigation worth US\$ 358-503 million TEV [46], Sundarbans Reserve Forest, Bangladesh / India services provided Wood, fuel wood, wild food, cultural services valued at US\$744,000 year-1 [47], Bontang City (Indonesia), the total benefits provided by mangrove forests are US\$ 351,801.67 year $^{-1}$ [48], Sinjai (Indonesia) the total value of economic benefits of mangrove is US\$1,016,581.04 while the total value of benefits per ha is US\$ 1,690.12 year $^{-1}$ [49], Banggai (Indonesia) with mangrove forest ecosystem \pm 167 ha, has a total economic benefit value of $1,969,766.07$ year $^{-1}$ [50]. Based on the facts that mangrove ecosystems can bring massive profits not only to humans but also to the environment especially for the marine environment. This study attempts to create a model of suitable mangrove ecosystem management in order to enhance the economic values in several small islands. This research took place in some small islands consisting of Lakkang Island (Makassar), Pannikiang Island (Barru), Tanahkeke Island (Takalar), Bangko-Bangkoang Island (Pangkep). The locations can be seen in the following figures. The main objective of this study is to determine a model for sustainable mangrove forest management in small islands in South Sulawesi, Indonesia

\section{Research Method}

All populations in this study are people aged $20-60$ years old who live in the small islands. The sampling technique is done by purposive sampling. Village officials, heads of fishermen groups and NGOs were also sampled in this study. In order to acquire accurate data from all samples, a depth interview conducted to obtain information from respondents by questioning face to face and using interview guidelines. To find out more about the situation, potential and specific problem (felt need) of the communities, the Participatory Rural Appraisal (PRA) approach carried out. Interview underwent with the relevant agencies, village officials, chairman of fishermen groups and NGOs. The data collected in this study consists of primary and secondary data. Primary data collected from the informants and respondents through direct interviews and field observation, discussions and FGD (Focus Group Discussion) while the secondary data obtained from books and journals. To collect the information, on the model of sustainable mangrove forest management and economic value in each island, interviews were conducted to village administrations, local authorities, community leaders and NGOs. Discussions with informal groups such as fisherman and farmer groups with a total of four meetings were conducted in each island. In Addition, some people of these islands who have extensive experience of mangrove forest management were also interviewed indepth. Interview, discussion, and FGD (Focus Group Discussion) are done with the PRA (Participatory Rural Appraisal) approach. Based on the cycle of the PRA phases, sequentially, the stages carried out in the Interview, discussion and FGD (Focus Group Discussion) focus on:

1. Potential natural resources of mangrove forests and small islands that can be utilized

2. Priority of management and utilization of mangrove forest resources

3. Patterns of management and utilization of mangrove forests which have been carried out so far by the community

4. The community habits in managing and utilizing each type of mangrove forest resources

5. Types of fishing gear / equipment used, in the mangrove forest area

6. Local rules, which apply in the community, regarding the management and utilization of mangrove forests

7. Possibilities of conflict of interest

8. Evaluation and follow-up plans as a result of interviews, discussions, and FGD (Focus Group Discussion) 


\section{Results and Discussion}

3.1 Mangrove ecosystem resource management technique.

a. Lakkang island

The mangroves in Lakkang Island are spread along rivers and estuaries. Mangroves are also found in pond embankments and behind residents. Nypa sp and Rhizophora mucronata are the most dominant species. In addition, other species can be found such as Sonneratia alba, Rhizophora apiculata, Achantus sp, Bruguiera gymnorrhiza, and Avicennia marina. The area of mangrove forest in Lakkang Island is about 9.8 hectare. The mangrove forest is utilized by the communities to catch fish, prawn, and crab around the mangrove forest area and distributed to the market nearby until Makassar City as a nearby city. In addition, Mangrove species such as nypa sp leaves can be used for material to produce traditional house roofs. Many people also visit this island to enjoy the view of Mangrove landscape especially on the weekend. Generally, there are several ways to utilize and manage the mangrove ecosystem in Lakkang Island such as:

1) Using fishing nets, traps, iron hooks to catch prawn and $\mathrm{crab}$

2) Developing mangrove nurseries with the extraction system from its fruit

3) Utilization of mangrove ecosystems as a place to enlarge crab cultivation

4) Planting on the edge of the embankment of the pond especially those facing directly to the river

b. Pannikiang Island

Mangroves grow and develop with a fairly high density and distribute along the coast of Pannikiang Island. Most mangrove species are Bruguiera gymnorrhiza, Sonneratia alba, Rhizophora apiculata, Bruguiera gymnorrhiza, and Avicennia marina. People in Pannikiang Island utilize mangrove forests to catch fish by using gill nets. The gill nets are installed when the water recedes and it is pulled when the tidewater rises.

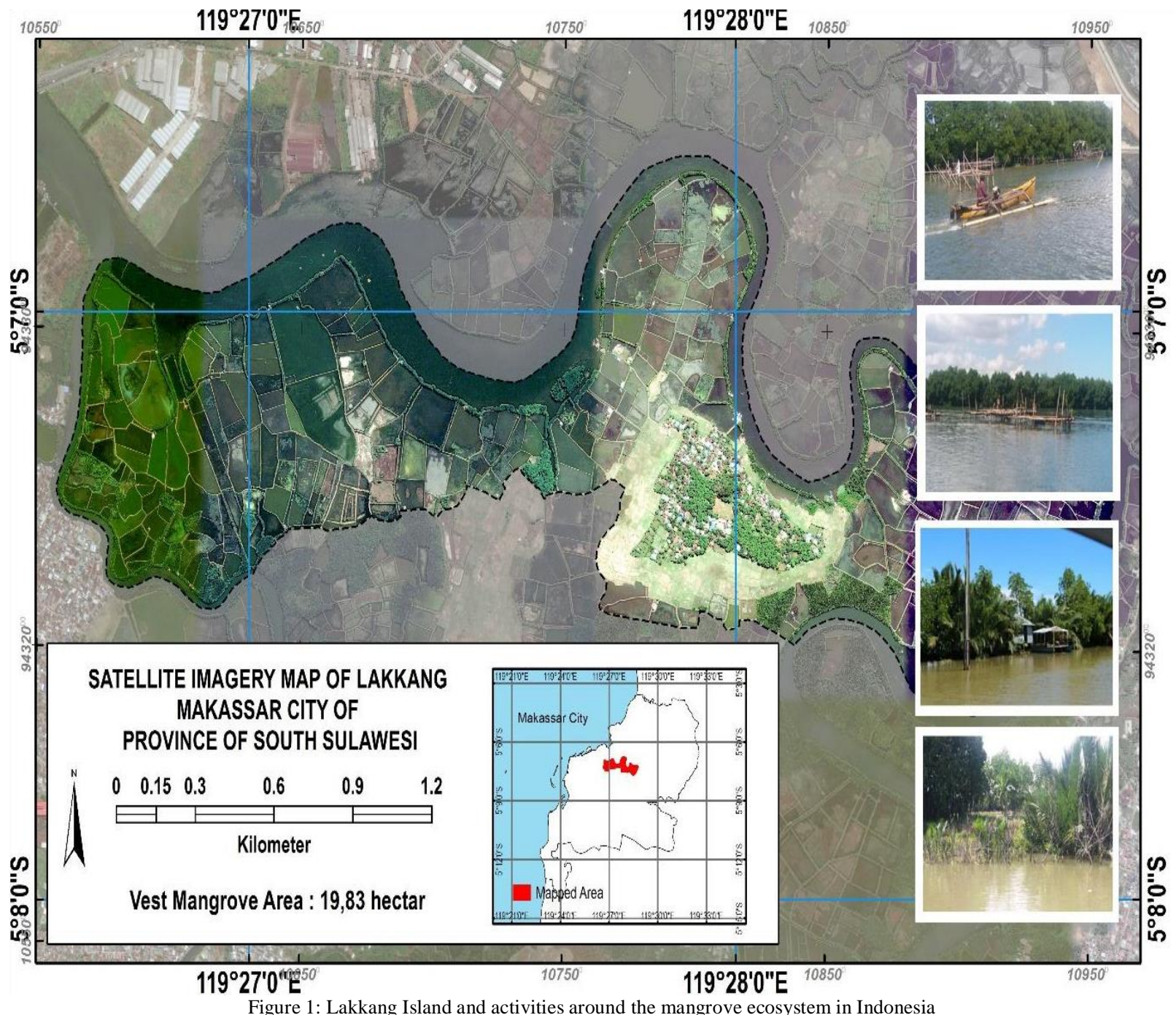


Mostly fishes that are caught are snapper, grouper and sometimes there are also crab and prawn. Around the mangrove forest area, there are also floating cages used to cultivate groupers and also utilized as a fishing spot. There are around 30 species of mangroves consisting of 17 species of true mangrove species and 13 other species of mangroves (associations). The true mangrove ecosystem in this island consist of Sonneratia alba, Rhizophora stylosa, Rhizophora apiculata, Bruguiera gymnorrhiza, Avicennia marina, Ceriops decandra, Ceriops tagal, and Lumnitzera racemosa. Whereas, the additional mangroves from the true mangroves consist of Aegiceras corniculatum, Excoecaria agallocha, Xylocarpus granatum, and Xylocarpus moluccensis. The mangrove forest on this island grows well and has beautiful form. Due to its beauty, this area becomes one of the coastal tourist destinations in Barru Regency. Generally, there are several ways to utilize and manage the mangrove ecosystem in Pannikiang Island such as:

1) Using gill nets and fishing rods

2) Using floating net cages around the mangrove forest area to cultivate fish

3) Using an iron hook and put a crab trap catching the crab

4) Utilizing the mangrove ecosystems as a place for crab cultivation in ponds

5) Catching bats that are found in mangrove forests by using nets.

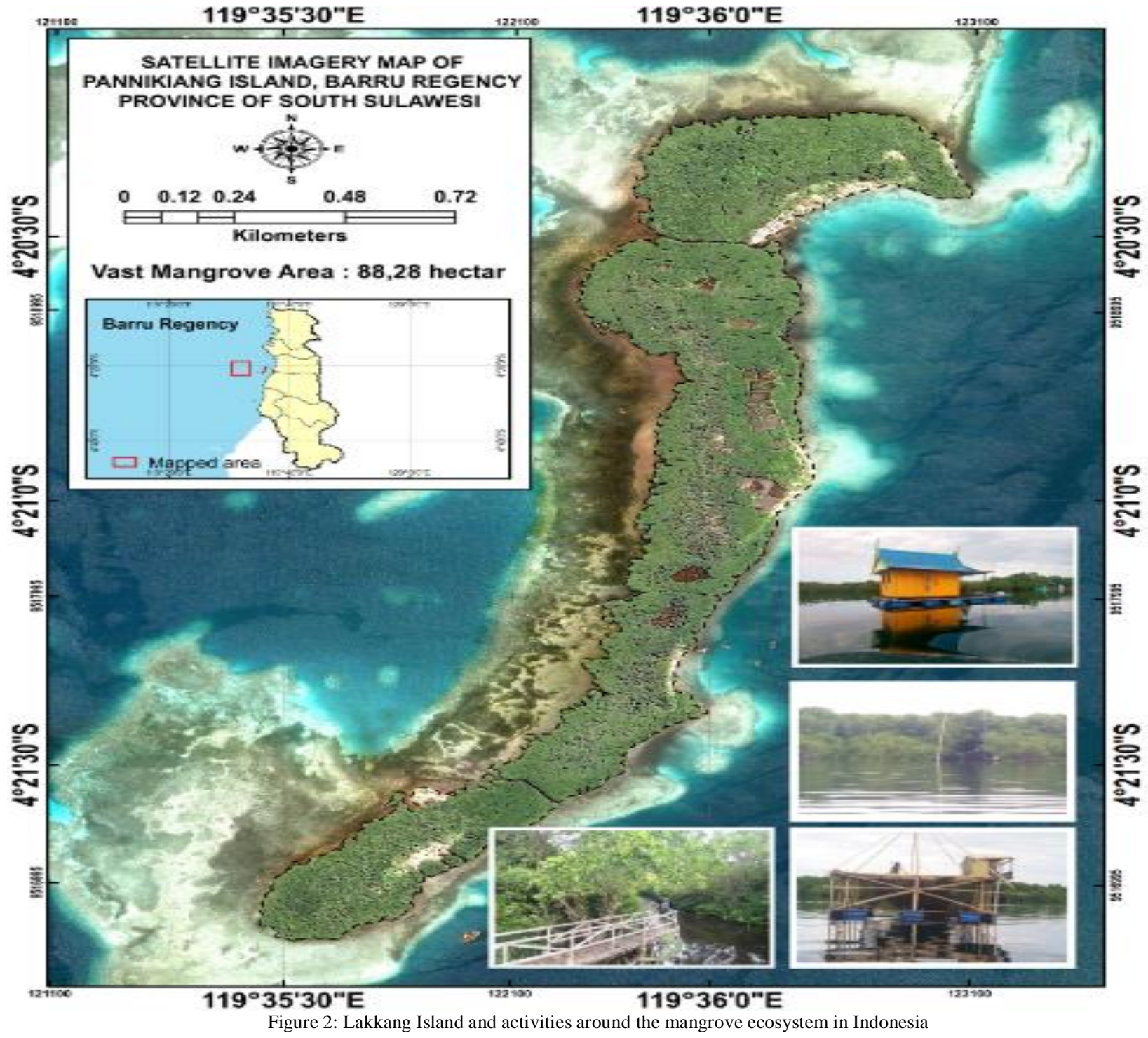


6) The local government should arrange a long gap that can divide the mangrove forest as a place for visiting tourists and for fishery

7) The local government can make gazebos and towers in the middle of the mangrove forest area so that the visitors can rest and climb the tower to see the entire stretch of mangrove forest on Pannikiang Island

8) Cultivation of silvofishery combines fish/ shrimp cultivation with mangroves.

\section{c. Tanahkeke Island}

The mangroves in Tanakeke Island are generally dominated by Rhizophora mucronata, Lumnitzera $s p$, and Sonneratia alba species while the other species such as Rhizophora stylosa, Rhizophora apiculata, Avicennia sp, Bruguiera gymnorrhiza can also be found. These kinds of Mangrove mostly located around residents area. Fishermen and aquaculture farmer utilize mangrove forest by catching fish, shrimp, shellfish, crab as well as harvesting mangrove fruits and mangrove wood. [51][52] stated that mangrove assets on Tanakeke Island is the largest mangrove ecosystem in South Sulawesi Province and it is covering 20\% area of the total mangrove ecosystem in South Sulawesi Province. Due to this potential, a lot of people rely on their life on the mangrove ecosystem. Furthermore, People in Tanakeke Island also utilize mangrove wood to make wood charcoal, then distribute it to Makassar City. [51] revealed that the process involved in mangrove wood becoming wood charcoal takes approximately a month which consists of three stages such as the preparation stage, the production stage, and the marketing stage. The preparation stage consists of logging, transporting and drying wood. Mangrove wood raw materials can be obtained from the island people's own land or they bought from other people or suppliers. This pattern of cooperation between suppliers and mangrove wood craftsmens is commonly called "Ponggawa-Sawi". Ponggawa is interpreted as the owner of the capital while Sawi is interpreted as a craftsman. Charcoal craftsmen are given money by people for raw materials. The component of this raw material is the largest component that must be issued by charcoal craftsmen because the price per hectare of mangrove ranges from 10-30 million IDR depending on the size of the stem and the density of the tree. With the high price of the mangrove wood, Ponggawa lent money to craftsmen in order to purchase the raw materials from the communities. Craftsmen and Ponggawa make agreement to return the loans at certain interest rates. In addition, charcoal craftsmen may not sell their wood charcoal to other parties.

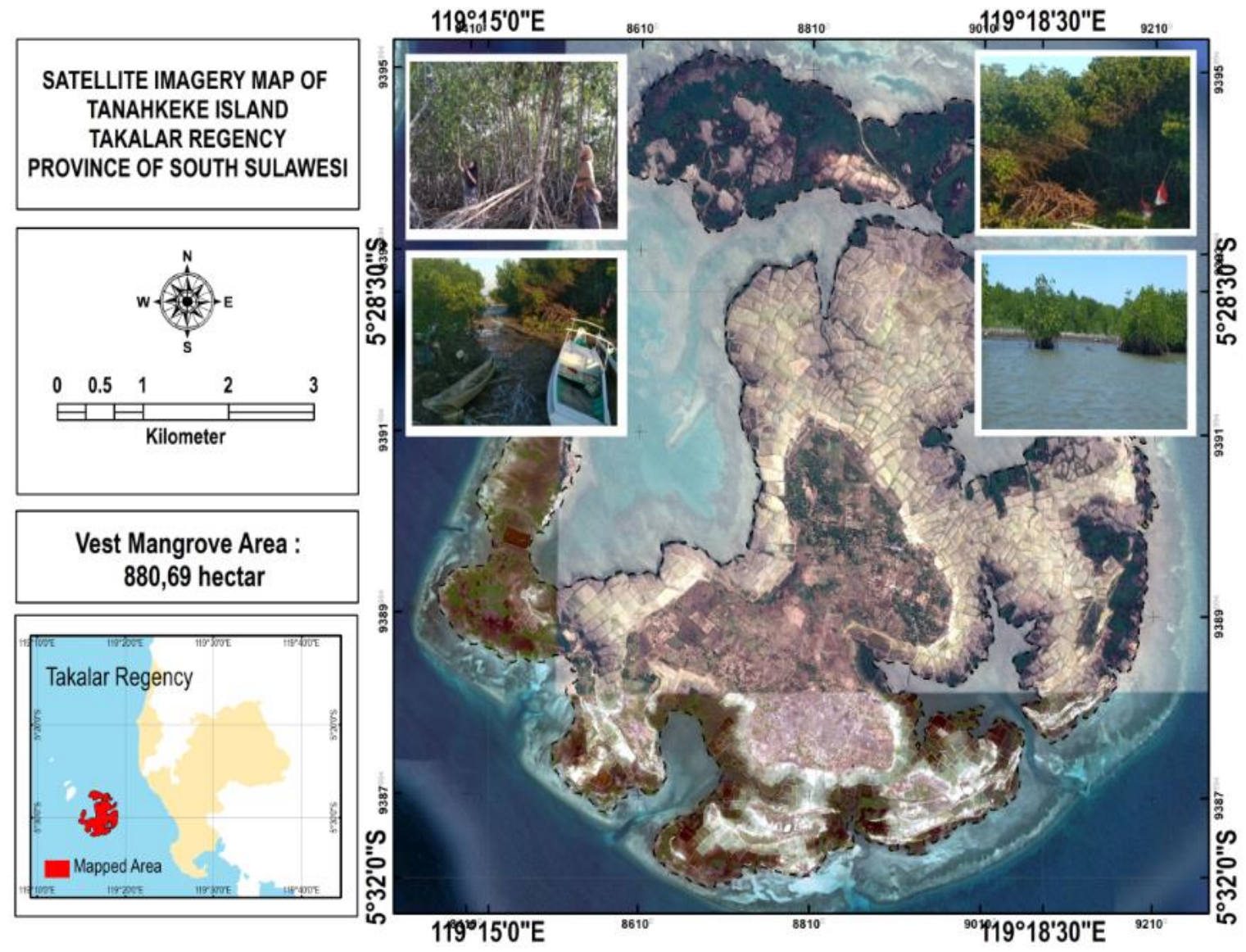

Figure 3: Lakkang Island and activities around the mangrove ecosystem in Indonesia 
After the charcoal is harvested, the craftsmen pay off the debt to the Ponggawa both the principal and the interest. Although Ponggawa often buy wood charcoal below the market price standards, wood charcoal craftsmen already consider it as a common and mutual benefit. Generally, there are several ways to utilize and manage the mangrove ecosystem in Tanakeke Island such as:

1) Using gill nets and fishing rods

2) Using an iron hook and put a crab trap known as a rakkang in local language for catching the crab

3) Utilization of mangrove ecosystems as a place for cultivating crab in ponds

4) Cultivation of ponds by converting mangrove land into ponds (mangrove clearing system which is used as cultivated area)

5) Utilizing mangrove fruit (Rhizophora sp.) to be used as seedlings and to be produced into snack and dessert (Bruguiera sp)

6) Utilizing mangrove wood into wood charcoal and firewood

7) Utilizing mangrove wood as a house pole

d. Bangko-bangkoang Island

The mangrove species are located in Bangkobangkoang Island such as Rhizophora stylosa, R.apiculata, R.mucronata,
Sonneratia alba and Avicennia marina. This mangrove ecosystem grows on the coastal area and is also found growing in the ponds scattered which can give benefits to people by providing fish, prawn, crab and firewood. Fish resources around the mangrove forest area are obtained by fishing and using gill nets. Fish species that can be caught are small white snapper, small red snapper, and small grouper. The fish that is caught then sold to the collectors. Meanwhile, shrimp resources are generally obtained by cultivating them in ponds in the mangrove forest area with traditional cultivation techniques. Aquaculture farming usually produces when the rainy season comes because at that time, the water has low salinity. Generally, there are several ways to utilize and manage the mangrove ecosystem in Bangko-bangkoang Island such as:

1) Using gill nets and fishing rods

2) Using an iron hook and put a crab trap known as a rakkang in local language for catching crab Utilization in mangrove ecosystems as a place for crab cultivation

3) Cultivation of ponds created by converting mangrove land into ponds (mangrove clearing system which is used as cultivation)

4) Utilizing firewood mangrove wood

5) Utilizing mangrove wood as a house pole

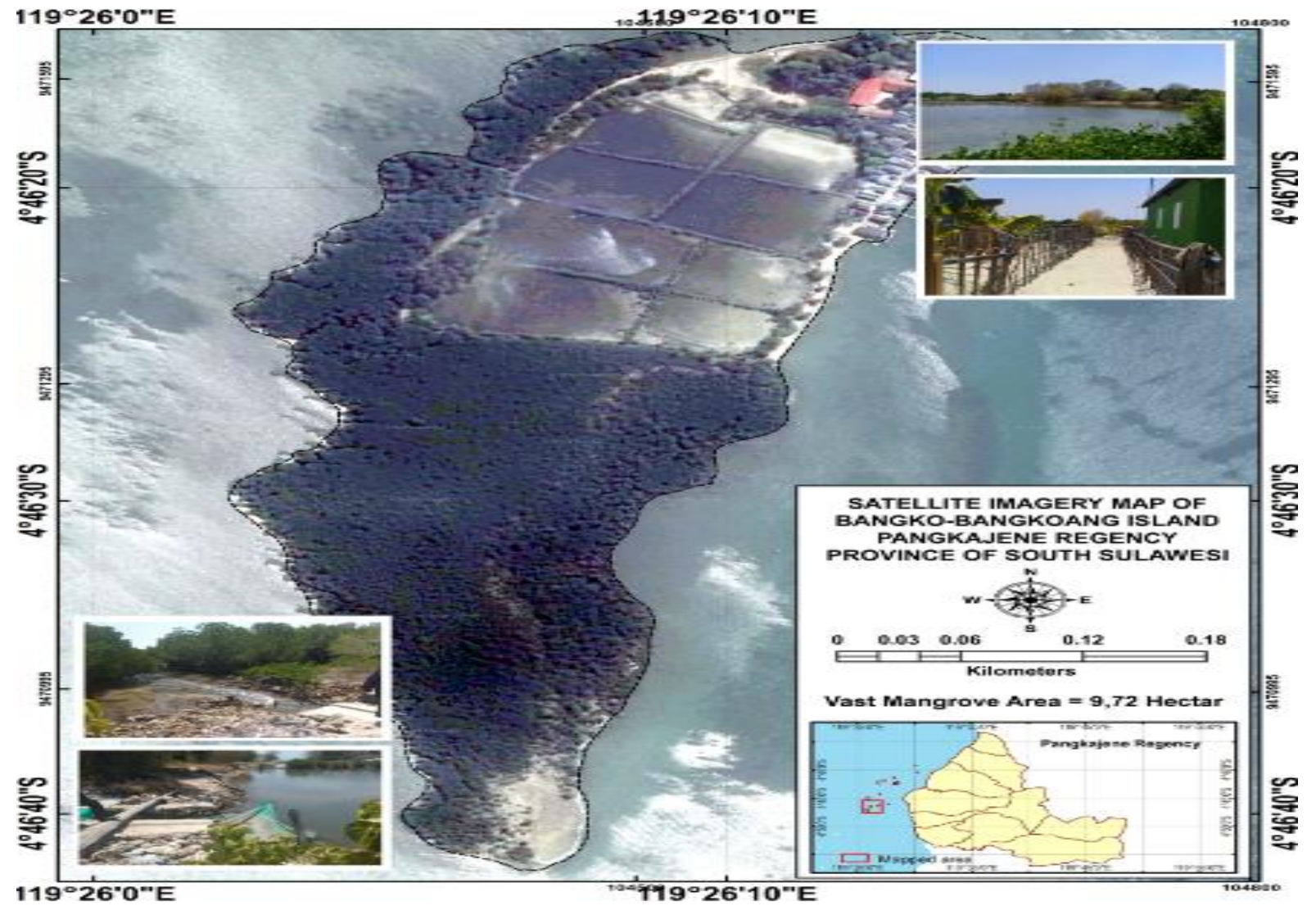

Figure 4: Bangko-bangkoang Island and activities around the mangrove ecosystem in Indonesia 


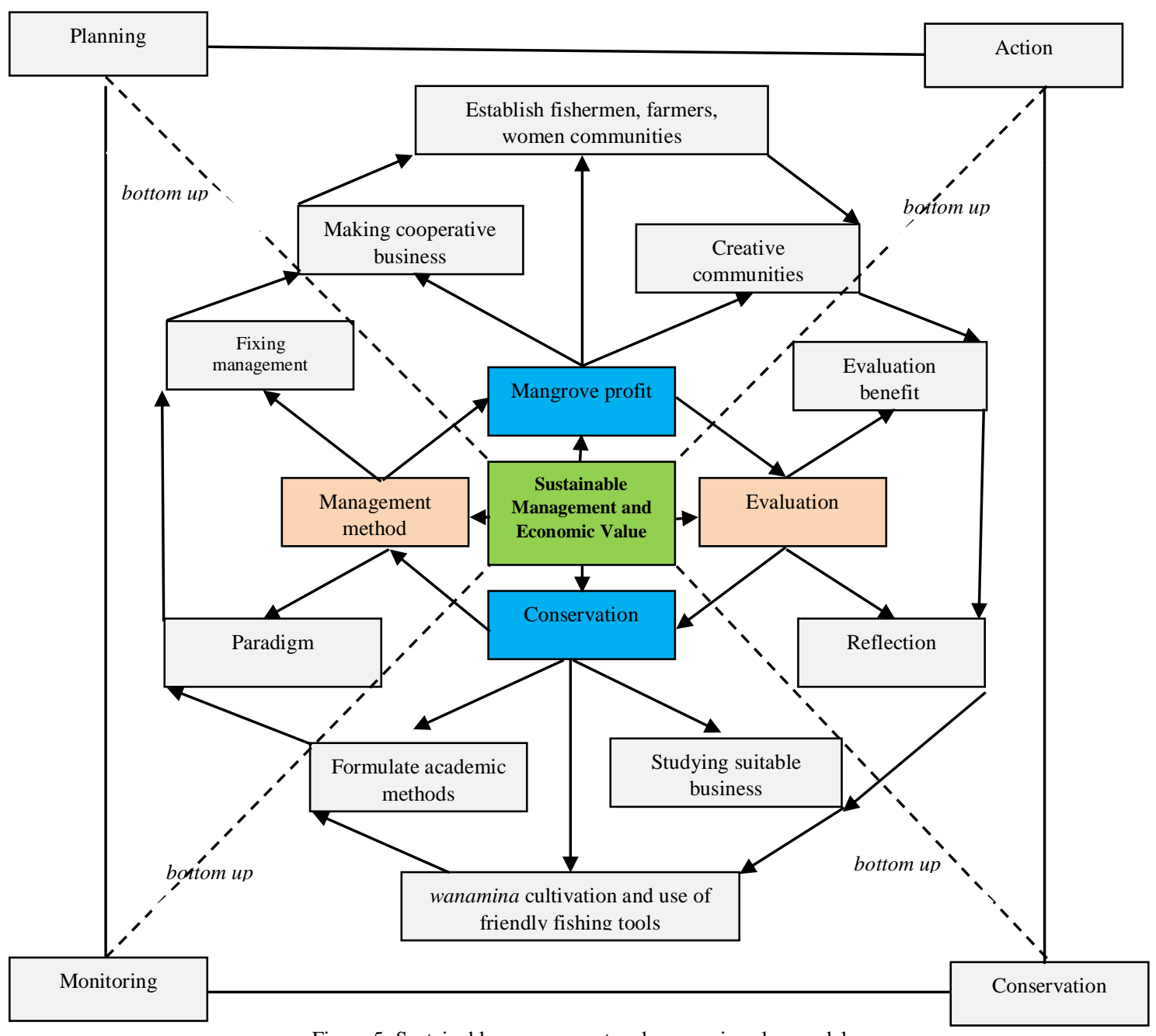

Figure 5: Sustainable management and economic value model

The sustainable and profitable management model of mangrove ecosystem resources consisted of 4 factors such as; 1) studying the analysis of mangrove forest benefits; 2) patterns and methods of management; 3 ) the concept of conservation; 4) evaluation. In addition to the implementation, the government acts as a motivator as well as a facilitator and bottom-up approach system to conduct the planning, implementing, exploring and supervising the management of mangrove ecosystem resources. The model of sustainable and profitable management of mangrove ecosystem resources in small islands starts to establish fishermen, aquaculture farmers, women communities consisting of 10-15 people that are able to produce products from mangrove forest. Therefore, these communities must have creativity because the business depends on the availability of mangrove resources. After building the communities, the next step is to profit from mangrove products. Besides, important to form academic methods to put the urgency and management paradigm of establishing important matters and the main patterns and models for the mangrove forests management. Then, fixing management access, and the last, forming a cooperative or jointly owned business entity.

\section{Conclusions}

The model starts with the formation of groups of fishermen/farmers /mangroves/women. The group produces something from mangrove forest that comes from creativity and ability to create something new as well as utilizing their members based on their abilities. After the formation of productive, creative and innovative groups of fishermen/ farmers / mangroves, the values and provided benefits are assessed. Before going to the next stage, reflection on the groups formed is under the goals and objectives of the group formation. After reflection, it conducts a study of the suitability of the business sector that is carried out in the mangrove forest area. The suitability of the business sector must be based on environmentally friendly systems and mangrove conservation. It is called cultivation with the silvofishery system (integrating shrimp/fish cultivation with 
mangroves) and the use of environmentally friendly fishing tools. The next step is to formulate academic methods, then lay down the urgency and management paradigm of putting something important and the main patterns and models in the management of mangrove forests. After that phase, fixing management problems of mangrove forest. Mangrove forest management involves local communities and other stakeholders meanwhile the government, in this case, acting as a motivator and facilitator.

\section{Acknowledgements}

The Authors express their gratitude to the KemenristekDikti who have given research grants (Grant Number: 99/UN36.9/PL/2019) and to the Chancellor of Makassar State University who provided various facilities in this research. Also to those who have helped in this study.

\section{References}

[1] Carugati L, Gatto B, Rastelli E, Martire ML, Coral C, Greco $\mathrm{S}$, Danovaro R. Impact of mangrove forests degradation on biodiversity and ecosystem functioning. Scientific reports. 2018 Sep 5;8(1):1-1.

[2] Romañach SS, DeAngelis DL, Koh HL, Li Y, Teh SY, Barizan RS, Zhai L. Conservation and restoration of mangroves: Global status, perspectives, and prognosis. Ocean \& Coastal Management. 2018 Mar 15;154:72-82.

[3] Costanza R, De Groot R, Sutton P, Van der Ploeg S, Anderson SJ, Kubiszewski I, Farber S, Turner RK. Changes in the global value of ecosystem services. Global environmental change. 2014 May 1;26:152-8.

[4] Yanagisawa H, Koshimura S, Miyagi T, Imamura F. Tsunami damage reduction performance of a mangrove forest in Banda Aceh, Indonesia inferred from field data and a numerical model. Journal of Geophysical Research: Oceans. 2010 Jun;115(C6).

[5] James GK, Adegoke JO, Osagie S, Ekechukwu S, Nwilo P, Akinyede J. Social valuation of mangroves in the Niger Delta region of Nigeria. International Journal of Biodiversity Science, Ecosystem Services \& Management. 2013 Dec 1;9(4):311-23.

[6] Abino AC, Castillo JA, Lee YJ. Assessment of species diversity, biomass and carbon sequestration potential of a natural mangrove stand in Samar, the Philippines. Forest science and technology. 2014 Jan 2;10(1):2-8.

[7] Sandilyan S, Kathiresan K. Mangroves as bioshield: an undisputable fact. Ocean \& Coastal Management. 2015 Jan 1;103:94-6.

[8] Kusmana C, Sukwika T. Coastal community preference on the utilization of mangrove ecosystem and channelbar in Indramayu, Indonesia. AACL Bioflux. 2018;11(3):905-18.

[9] Chen L, Wang W, Zhang Y, Lin G. Recent progresses in mangrove conservation, restoration and research in China. Journal of Plant Ecology. 2009 Jun 1;2(2):45-54.

[10] Saprudin S, Halidah H. The potential and value of environmental services of mangrove forests in Sinjai Regency South Sulawesi. Jurnal Penelitian Hutan dan Konservasi Alam. 2012;9:213-219.

[11] Carandang AP, Camacho LD, Gevaña DT, Dizon JT, Camacho SC, de Luna CC, Pulhin FB, Combalicer EA, Paras FD, Peras RJ, Rebugio LL. Economic valuation for sustainable mangrove ecosystems management in Bohol and Palawan, Philippines. Forest science and technology. 2013 Sep 1;9(3):118-25

[12] Widiastuti MM, Ruata NN, Arifin T. Economic valuation of mangrove ecosystem in coastal in Merauke Regency. Jurnal Sosial Ekonomi Kelautan dan Perikanan, 2016;11:147-159.
[13] Idrus S, Ismail A, Ekayani M. Potential payments for environmental services of mangrove forests in West Halmahera Regency. Jur. Ilmu. Pert. Indo. 2017;21:195-202.

[14] Small N, Munday M, Durance I. The challenge of valuing ecosystem services that have no material benefits. Global Environmental Change. 2017 May 1;44:57-67.

[15] Albert JA, Schwarz AM. Mangrove management in Solomon Islands: case studies from Malaita Province. CGIAR Research Program on Aquatic Agricultural Systems. Penang, Malaysia. Policy Brief AAS. 2013;14.

[16] Kathiresan K, Bingham BL. Biology of mangroves and mangrove ecosystems. Advances in marine biology. 2001 Dec;40:84-254

[17] Noor TA, Batool NA, Mazhar RO, Ilyas NO. Effects of siltation, temperature and salinity on mangrove plants. European Academic Research. 2015;2(11):14172-9.

[18] Nehru P, Balasubramanian P. Re-colonizing mangrove species in tsunami devastated habitats at Nicobar Islands, India. Check List. 2016 Dec 13;7(3):253-6.

[19] Blankespoor B, Dasgupta S, Lange GM. Mangroves as protection from storm surges in a changing climate. The World Bank; 2016 Mar 14.

[20] Jia M, Wang Z, Zhang Y, Ren C, Song K. Landsat-based estimation of mangrove forest loss and restoration in Guangxi province, China, influenced by human and natural factors. IEEE Journal of Selected Topics in Applied Earth Observations and Remote Sensing. 2014 Aug 5;8(1):311-23.

[21] Walters BB, Rönnbäck P, Kovacs JM, Crona B, Hussain SA, Badola R, Primavera JH, Barbier E, Dahdouh-Guebas F. Ethnobiology, socio-economics and management of mangrove forests: A review. Aquatic Botany. 2008 Aug 1;89(2):220-36.

[22] Spalding M. World atlas of mangroves. Routledge. 2010;1257

[23] Gasaneat JK, Borobia M. ITTO projects in Columbia,, Panama, Thailand, India and Japan: the course of mangrove conservation and sustainable management. Tropical Forest Update. 2004;14(4):14.

[24] Murray MR, Zisman SA, Furley PA, Munro DM, Gibson J, Ratter J, Bridgewater S, Minty CD, Place CJ. The mangroves of Belize: Part 1. distribution, composition and classification. Forest Ecology and Management. 2003 Feb 17;174(1-3):265-79.

[25] Liu K, Li X, Shi X, Wang S. Monitoring mangrove forest changes using remote sensing and GIS data with decision-tree learning. Wetlands. 2008 Jun 1;28(2):336-346.

[26] Nagelkerken IS, Blaber SJ, Bouillon S, Green P, Haywood M, Kirton LG, Meynecke JO, Pawlik J, Penrose HM, Sasekumar A, Somerfield PJ. The habitat function of mangroves for terrestrial and marine fauna: a review. Aquatic botany. 2008 Aug $1 ; 89(2): 155-85$.

[27] Hogarth PJ. The biology of mangroves and seagrasses. Oxford University Press; 2015.

[28] Manson FJ, Loneragan NR, Phinn SR. Spatial and temporal variation in distribution of mangroves in Moreton Bay, subtropical Australia: a comparison of pattern metrics and change detection analyses based on aerial photographs. Estuarine, Coastal and Shelf Science. 2003 Jul 1;57(4):653-66

[29] Able KW. A re-examination of fish estuarine dependence: evidence for connectivity between estuarine and ocean habitats. Estuarine, coastal and shelf science. 2005 Jul 1;64(1):5-17.

[30] Arfan A, Tuafieq NAS. Mangrove forest management on local communities based in South Sulawesi, Indonesia. Ecol. Environ. Conserv. 2017;23 (1): 77-83.

[31] Arfan A, Abidin MR, Leo NZ, Sideng U, Nympa S, Maru R, Syarif E, Lao Y. Production and decomposition rate of litterfall Rhizophora mucronata. Environment Asia. 2018;11(1):112-24.

[32] Toriman ME, Arfan A, Yusop Z. Assessment of Mangrove Water Quality by Multivariate Statistical Analysis in Suppa 
Coast, South Sulawasi, Indonesia. World Applied Sciences Journal. 2013;28(9):1301-10.

[33] Setiyowati D, Supriharyono S, Triarso I. Valuasi ekonomi sumberdaya mangrove di Kelurahan Mangunharjo, Kecamatan Tugu, Kota Semarang Economic Valuation of Mangrove Resources in the Mangunharjo Village Tugu Sub District, Semarang City. Saintek Perikanan: Indonesian Journal of Fisheries Science and Technology. 2017;12(1):67-74

[34] Davinsy R, Kustanti A, Hilmanto R. Kajian Pengelolaan Hutan Mangrove Di Desa Pulau Pahawang Kecamatan Marga Punduh Kabupaten Pesawaran (Study Of Mangrove Forest Management In The Pahawang Island Village Marga Punduh District Pesawaran Regency). Development. 2015 Sep;3(3):95106.

[35] Schaduw JN. Keberlanjutan pengelolaan ekosistem mangrove Pulau Mantehage, Kecamatan Wori, Kabupaten Minahasa Utara Provinsi Sulawesi Utara. Jurnal LPPM Bidang Sains dan Teknologi. 2015;2(2):60-70.

[36] Khoirul U. Strategi Pengembangan Ekowisata Mangrove Wonorejo Surabaya (Doctoral Dissertation, Upn" Veteran" Jatim). Surabaya Strategi Pengembangan Ekowisata Mangrove Wonorejo Surabaya Development Strategy of Mangrove Ecotourism in Wonorejo, Surabaya. 116(1):35-42.

[37] Richards DR, Friess DA. Rates and drivers of mangrove deforestation in Southeast Asia, 2000-2012. Proceedings of the National Academy of Sciences. 2016 Jan 12;113(2):344-9.

[38] Liingilie AS, Kilawe C, Kimaro A, Rubanza C, Jonas E. Effects of salt making on growth and stocking of mangrove forests of south western Indian Ocean coast in Tanzania. Mediterr J Biosci. 2015;1:27-31

[39] He B, Li R, Chai M, Qiu G. Threat of heavy metal contamination in eight mangrove plants from the Futian mangrove forest, China. Environmental geochemistry and health. 2014 Jun 1;36(3):467-76.

[40] Dilmaghani Y, Danehkar A, Jozi SA, Arjomandi R. Codification of mangrove forests management strategies: Case study of Hara Protected Area, Iran. Journal of Food Agriculture \& Environment. 2011 Apr 1;9(2):508-13.

[41] Lee SY, Primavera JH, Dahdouh-Guebas F, McKee K, Bosire JO, Cannicci S, Diele K, Fromard F, Koedam N, Marchand C, Mendelssohn I. Ecological role and services of tropical mangrove ecosystems: a reassessment. Global ecology and biogeography. 2014 Jul;23(7):726-43.

[42] Barbier EB. Valuing the environment as input: review of applications to mangrove-fishery linkages. Ecological economics. 2000 Oct 1;35(1):47-61.

[43] Spurgeon JJ. Socio-economic Assessment and Economic
Valuation of Egypt's Mangroves: Rehabilitation, conservation and sustainable utilization of mangroves in Egypt. Working Paper-FSFM/VAL/02, 51pp. Online at: http://www. fao. org/docrep/007/ae212e/ae212e00. htm; 2004.

[44] Baig SP, Iftikhar UA. Are the Mangroves for the Future? Empirical evidence of the value of Miani Hor Mangrove Ecosystem as the basis for investments. IUCN. Karachi. 2010.

[45] Brander LM, Wagtendonk AJ, Hussain SS, McVittie A, Verburg PH, de Groot RS, van der Ploeg S. Ecosystem service values for mangroves in Southeast Asia: A meta-analysis and value transfer application. Ecosystem services. $2012 \mathrm{Jul}$ $1 ; 1(1): 62-9$

[46] Kuenzer C, Tuan VQ. Assessing the ecosystem services value of Can Gio Mangrove Biosphere Reserve: Combining earthobservation-and household-survey-based analyses. Applied Geography. 2013 Dec 1;45:167-84.

[47] Kuenzer C, Tuan VQ. Assessing the ecosystem services value of Can Gio Mangrove Biosphere Reserve: Combining earthobservation-and household-survey-based analyses. Applied Geography. 2013 Dec 1;45:167-84.

[48] Uddin MS, van Steveninck ED, Stuip M, Shah MA. Economic valuation of provisioning and cultural services of a protected mangrove ecosystem: a case study on Sundarbans Reserve Forest, Bangladesh. Ecosystem Services. 2013 Sep 1;5:88-93.

[49] Sunaryo B, Yudistyana R, Firaldy AT. The Valuation of Mangrove Forest Economy of Community Development Program of Badak LNG. Economics Development Analysis Journal. 2018 May 31;7(2):120-7.

[50] Tahang H, Amiluddin A, Amir F, Firman F. Economic Valuation of Mangrove Forest Ecosystem in Sinjai. TORANI: Journal of Fisheries and Marine Science. 2018 Jul 7;1(2):71-80.

[51] Putranto S, Zamani NP, Sanusi HS, Riani E, Fahrudin A. Economic Valuation Of Mangroves Forest Resources In Regency Of Banggai dan Banggai Island Central Sulawesi. Jurnal Ilmu dan Teknologi Kelautan Tropis. 2017;9(2):645-56.

[52] Setiawan H. Studi pengelolaan hutan mangrove sebagai bahan baku industri arang di Pulau Tanakeke Kabupaten Takalar Sulawesi Selatan. InSeminar Nasional Sewindu BPTHHBK Mataram: Pengarusutamaan Hasil Litbang Lingkungan Hidup dan Kehutanan sebagai Lokomotif Pembangunan Berkelanjutan 2015 Mar (pp. 597-605).

[53] Arfan A, Sanusi W, Rakib M, Taufieq NA. Economic Value of Mangrove Forest in Pannikiang Island, Barru District, South Sulawesi, Indonesia. InJournal of Physics: Conference Series 2019 Jun (Vol. 1244, No. 1, p. 012015). IOP Publishing. 